切除例の検討一ss癌を中心に一

昭和大学一般・消化器外科

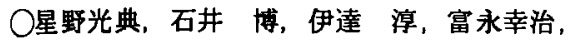

小池 康，榎澤哲司，大堀真媇，大山样，

太田 篤, 草野満夫

「目的」教室の胆囊癌切除例の壁深達度別治療成繶か

ら，特にss癌における適正な治療法を検討した。「対

象」過去12年間に切除した胆衰癌34例で，内訳はm

瘦 3 例， mp䍃 6 例，ss癌10例， se,si癌15例（Stage I 9 例，II 8 例，III 7 例，IVa6 例，IVb4 例) である。 「成績」手術術式はm癌 3 例では胆摘 3 例， $\mathrm{mp}$ 程 6 例で胆摘 3 例, 旰床切除十胆管切除 2 例, 胆摘+胆 管切除 1 例，ss癌 10 例では胆摘 3 例，肝床切除 6 例， 旰床切除十管切除 1 例, se, si漓15例では訮切除 + 胆管切除 7 例，肝切除 4 例，肝切除+膵頭十二指晹切 除 2 例，胆摘および胆摘+胆管切除各 1 例であった。 深達度別 5 年生存率は $\mathrm{m}$ 癌 $100 \%, \mathrm{mp}$ 腹 $66.7 \%, \mathrm{ss}$ 癌

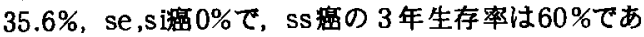
った. ly,pn,hinf, binf,リンパ節転移陰性例は予後が 良好で根治度AはB,Cに比べ有意に予後が良好であつ た.「結語」ss癌は長期生存の可能性があり，根治度 Aを目指した手術を施行すべきと考えられた

\section{4 進行胆要癌に対する術式の選択}

東京女子医科大学附属第二病院外科

○土屋玲,熊沢健一,塩澤俊一,増田俊夫。

大石传典，細川俊彦，涳田公一,押部信之，出口義雄， 高橋弘,金達浩，小川健治，芳賀駿介，梶原哲郎

【目的〕進行胆囊癌の進展様式，予後からみた適切術 式について検討した。〔対象〕過去18年間に当科で切 除した深達度ss以上の51例を対象とした.【結果〕 51 例の内訳はss 29例, se 12例, si 10例で，術式は胆摘 9 例, 肝床切除7例，肝床切除十胆管切除5例，肝亜区域 (S4a+5)切除9例，拡大右葉切除5例，肝切除十膵頭十 二指腸切除16例であった，多变量解析ではbinfが最も 重要な予後規定因子で(p<0.0001)，5生率ではbinf(-) $42.2 \%$, binf(+) 0\%と有意差を認めた(Logrank test : $\mathrm{p}<0.0001)$ ．当科ではbinf(-), $\mathrm{n}_{2}(+)$ をD $+\mathrm{D}_{3}$ の適応 とし ss, hinf1b, binfo, $\mathrm{n} 3(+) て ゙ 5$ 年生存例を得た。 hinfに関してはhinf1a, binfo, noに訮床切除を行い局所 再発した症例があり ss, hinf2, binfoにS4a+5切除， si， hinf3. binfo, noに払大右萊切除を施行しいずれも 5 年 生存を得た.〔結論〕1. $\operatorname{binf}(-)$ が長期生存の条件であ つた. 2. $\operatorname{binf}(-), \mathrm{n} 2(+)$ はD $+\mathrm{D} 3$ の適応と考えられた。 3. binf(-), n2(+)以下でhinf1a-2は肝亜区域 $(S 4 a+5)$ 切 除，hinf3は抎大右葉切除が基本術式と考えられた。
945 low dose CDDP-5FU 動注化学裳法が有

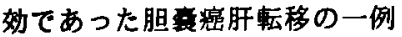

大阪医科大学一般・消化器外科

○大谷昌裕、森田员照、石橸孝䦜、原均、左古昌葴、 野村栄治、渡辺一三、土肥健彦、岩本充彦、谷川允彦

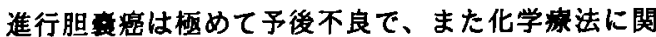
しても有奻な治廉法は確立していない。今回我々は肝 転移を伴った切除不能胆蜜密症例に対して、low dose CDDP-5FU(FP)動注化学療法を行い著奻を得たので報 告する。

【症例】66 歳、女性。全身供急感を主訴に近医を受診。 当院へ精查目的で紹介入院し、諸検查の結果、肝転移 を伴った胆言嶨が疑われた。開腹術を施行したか、根 治切除は不能であり、胆表摘出術と肝動脈チュービングを 行った。術後は原発巣およひ肝転移䉾に対して FP 動 注化学凄法(CDDP $10 \mathrm{mg} / \mathrm{day}, 5 F U 250 \mathrm{mg} / \mathrm{day}, 5$ 投 2 休、5 週間)を施行した。軽度の食欲不振を認めたが、 骨蹃抑制や腎障害はみられず、治療後 CEA は $114.5 \mathrm{ng} / \mathrm{ml}$ から $0.8 \mathrm{ng} / \mathrm{ml}$ に低下し、CT 上も治㙩奻果 はPRであった。

【まとめ】 low dose FP 動注化学㙩法は、今後進行胆震 密の治療法として期待し得るものと考えられた。

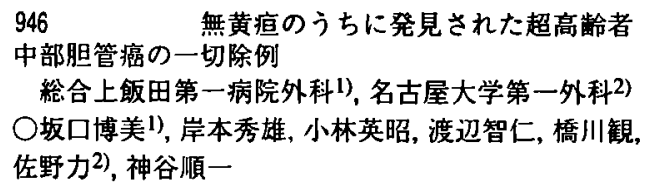

(はじめに) 無黄㾝のうちに中部胆管癌が診断される ことは少ない。一方, 周術期管理の向上から最近では 脺頭十二指腸切除 (PD) は安全になり, 高龄者にも適用 されるようになってきた. (症例) 81歳女性. 腹部膨満 感を主訴に近医受診.肝機能異常を指摘され，精査の ため当院に入院. CT, USでは，胆篹結石，胆变腺筋症と 診断した. ERCPでは三管合流部に約30mmにわたる偏 側性の不整な陰影欠損を認め，同部位からの透梘下生 検の結果は腺癌であった. 胆管造影像及びIDUS所見か らは表層拡大進展を示唆する所見は得られなかった。 年龄を考虑して神経諁部清を行わず带全胃温存PD (D2 郭清) を施行した. 切除標本では $29 \times 28 \mathrm{~mm}$ の乳頭型の 腫瑏で, 病理組織学的には中分化型管状腺癌, 深達度ss で,リンパ節転移，神経周囲浸潤は認めなかった. stage II, 根治度Aであった，術後経過は良好で第20病日に経 口揸取を開始し，第43病日に退院した。術後6月の現在, 再発の徴候なく経口摄取良好で, 元気に家庭生活を送 っている.(まとめ) 無黄㾝で発見された超高龄者の中 部胆管癌症例に对し亜全胃温存PDを施行し良好な結 果を得た。 
て術前確定診断が得られた微小胆管哆の1例

㕵マリアンナ医科大学東横病院外科，同第一外科 ${ }^{11}$

同病理 $^{2)}$

○須田直史、白田 裕、磯貝晶子、松崎弘明 小笹貴夫、足立幸博、朝合隆晴、木村正之 山村卓也 山口 晋" 品川俊人 ${ }^{2)}$

胆管痹は進行して発見されることが多く $1 \mathrm{~cm}$ 以下の病 変で発見されることは極めてまれである。今回我々は、 PTCDから細径胆道鏡（オブティスコーブ）を用いた 生検によって、術前確定診断が得られた微小胆管瘭の I例を経験したので文献的考察を加えて報告する。 【症例】61歳女性。平成10年11月20日㥧黄疸出現。 次第に黄㾝增悪し体重減少し伴ってきたため12月9日 当院受診。生化学検查所見では閉塞性黄㾝バターンを 示し、腹部CTにて下部胆管の狭囬、胿内胆管の拡張 が著明であったためPTCD捙入し人院となった。胆汁 細胞診ではClass I 〜 II 、腹部US,CT,MRにて下部胆管

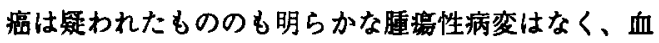
管撮影もとくに異常は認めなかった。そこで我々は PTCDより細径胆道鏡を括入し観察したところ下部胆 管に顆柆状の腫㻛性隆起を認め、同部位よりの生検に てAdenocarcinomaを認めたためPDを施行した。術後 病理学的検查にて $1 \mathrm{~cm}$ 以下の微小胆管癌であった。

948 術前診断に難跌した下部胆管徧平上皮

癌

和歌山県立医科大学 第 2 外科

大西博信, 谷村弘, 山上裕機, 内山和久, 瀧藤克也 谷 県至, 木下博之, 川井学, 冨永敏治, 小澤 悟

下部胆管の扁平上皮癌との術前診断に難渋した症例 を経験したので，文献的考察を加えて報告する.

[症例] 64歳の男性で，黄疸を主訴に内科に入院した。 血清総ビリルビン值 $9.7 \mathrm{mg} / \mathrm{dl}$ となり，PTCDを受け，外 科に紹介された。PTC造影にて下部胆管に狭窄像を認 めたが, 腹部CT, PTCS, IDUSを施行するも明らかな 腫瘍像を認めず, 腫癌マーカーはCA19-9のみ42U/ml 上昇していた。しかし，2度目の狭窄部の直接生検に てcarcinoma之診断され，入院後4力月目に幽門輪温存脺 頭十二指腸切除術を施行した $\left(\mathrm{S}_{0}, \operatorname{Hinf}_{0}, \mathrm{H}_{0}, \mathrm{Ginf}_{0}\right.$, Pancl， $D_{0}, V_{0}, P_{0}, N_{0}, M_{0}$, Stage II)。腫㾤は長径 $3 \mathrm{~cm}$ の結節浸潤型であり, 病理組織学的には扁平上皮癌 であった。術後34日目より5-FU 500mg, CDDP 10mgを5 日間投与し，45日月に退院した。術後1年6力月の現在, 再発を認めない。

[結語］胆管の腺届平上皮癌の報告は散見される。し かし、純粋な扁平上皮癌は極めてまれであり，その存 在に留意すべきである。
949 PTCで総胆管結石に類似した像を呈し、 胆汁細胞診で下部胆管腺扁平上皮癌と診断し得た 1 例 和泉市立病院外科 " 、同病理 ${ }^{2)}$

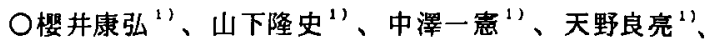
藤原一郎 " 、富土原知史 ${ }^{1}$ 、澤田隆吾 ${ }^{11}$ 、林部 音 ${ }^{11}$ 、 鬼頭秀樹 " 、阪本一次 " 、柳善佑 ${ }^{1}$ 、十倉寛治 ${ }^{\prime \prime}$ 、 浅田健蔵 ${ }^{1}$ 、竹林 淳 ${ }^{11}$ 、田中 勲 ${ }^{21}$

症例は65歳、女性。主訴は黄疾。腹部超音波、CT にて総胆管結石による閉塞性黄㾝が疑われ、PTCDを 施行した。造影にて総胆管末端で逆り字形の完全閉塞 を示した。しかし、胆汁細胞診にて扁平上皮癌及び腺 癌細胞を検出し、PTCD，BRＣによるはさみうち造影を 行ったところ、膵内胆管に不整な全周性狭窄ならびに EUSにて同部にheterogeneousな充実性腫韵を描出し たため下部胆管腺扁平上皮癌と診断し、膆頭十二指腸 切除術を施行した。膵内胆管に3×2 cm大の黄白色、 結節浸潤型の腫瘍を認めた。組織学的にadenosquam ous cell carcinom a, $\mathrm{S} I, H$ in $\mathrm{f} 0, \mathrm{H} 0, \mathrm{G}$ in $\mathrm{f} 0$, panc2, d0, PV0, A 0, P0, n (-), M (-), st(-), stage II, D 2，CuraAであった。術後約 1 年であるか、再発の兆 候は認めていない。。胆管腺扁平上皮滵は比較的稀な 疾患で本邦では最近20年間で20例の報告がみられる のみであり、文献的考察を加えて報告する。

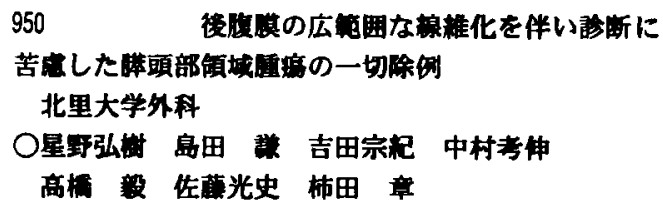

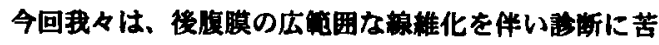

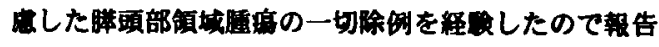
する。症间]54 才、女性。98 年6月20日頃より 食啳の大量胆吐を証めるようになり、7月 4 日当院外 来受喰した。同日、精查加嫽目的に入院となった。画

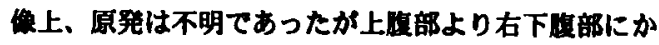
け広筑囲な進展形式を示す腫病であった。我々は Malignant fibrous histiocytoma や平滑觔肉尰を策い

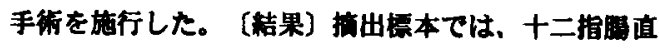

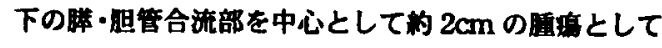

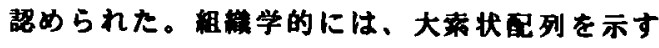
adeno-squamous carcinoma がシート状あるいは一 部で管状を形成しながら增生していた。以上より、本

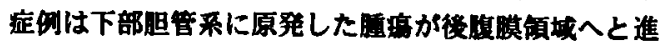
展したものと考えた。〔結語〕照管にたける adeno-squamous carcinoma の非度は、2〜6.5\%て あり、文献的にも少ない。また、この䇐な進展形式を 呈した症例は、当施設において、はじめてでっった。 
951

\section{脈嘴の 1 治跒例}

春日井市民病院 外科

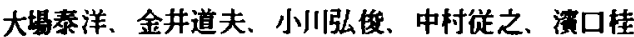
村秘三、山田英贯 朴哲浩、佐藤煡一郎、矢野孝

症例は 89 歳女性。平成 11 年 1 月 11 日黄疸で近 医より紹介された。血清ビリルビン值は $24 \mathrm{~m} \mathrm{~g} / \mathrm{d} 1$ で，腹部 C Tで総胆管下部に不均一に造影される部分 が見られそれより上流は $24 \mathrm{~mm}$ 拡張し主䐙管も 1 $0 \mathrm{~mm}$ と拡張していた。直径 $5 \mathrm{~cm}$ の堅下腹大動脈痹 も契められた。経皮経肝胆道ドレナージを行い減黄し つつ棈查し治切除可能な下部胆管痁と診断した。手 術は人工血管感染を考虑し 2 回に分けた。腹部手術後 腹大场脈㿔の急速な增大が見られる事があることと， 腹大野脈瘦手術の方が術後の患者回復の期間が短い事 を考六腹大勏脈癌の手術を先に行った。2月 24 日左 腹埂外到迲法を用いて腹大地脈瘦切除術を行った。Y 型人工血管を使用し中枢側吻合部は大動脈壁で夏われ るように吻合した。術後経過は良好であったが多発性 胃溃富による下血が見られ溃分の改善を待って 3 月 3 0日䐙頭十二指腸切除術を行った。消化性胃溃病ある ため幽門何胃切除を追加し C h ild 変法を用いて再建 した。術後は良好に経過し 4 月 27 日退院された。

952 胆管原発小細胞疰の一例

富山桇立中央病院外科 "、同臨床病理科 O宮下知治 "、小西孝司 "，能登正浩 "，田代聖子 "、谷口桂 三”、加治正英 ”、木村莌伸 "、前田基一 ”、渎下和久 "、辻 政彦 "1,三得夫

消化器領城における小細胞瘏症例の報告は食道や大渴など でみられるものの願度の低い知患である。その中でも胆管を

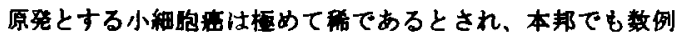

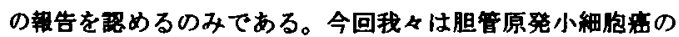

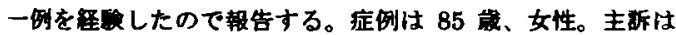

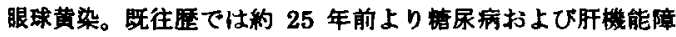
客にて加荌中であった。1999 年 2 月下旬、近医にて黄疸を指 揞され、当院を紹介された。入院時の CT、MRI にて総胆管

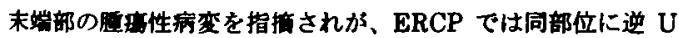
字を呈する大きな久損像が㗏められ、結石も考㥁された。 PTCD にて娍黄後、1999 年 3 月 30 日手術を施行した。幽門 㢵温存腾頭十二指渴切除術が最善の手術ではあるが、高龄お

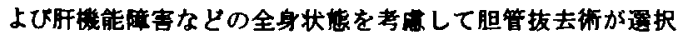
された。しかし術中、出血㑯向および血圧低下を来したため

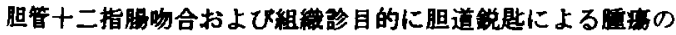

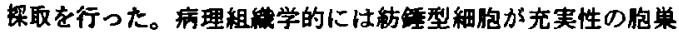
を形成しながら密に增票する像を呈し、免度組維化学的には NSE が強隔性、クロモグラニン A が弱隄性であり、胆管を

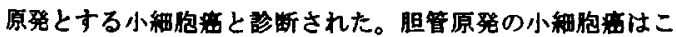
れまで数例しか教告されておらず、若干の文献的考察も加え て啹告する。
953 膵浸䦥を伴った十二指晹乳頭部，小

細胞癌の一切除例

秋田大学 外科, 病理部*

○古屋智規，浅沼義博，田中㳯一，安藤秀明，

提崲宣人*，小山研二

症例は68䠞，男性。黄疸が出現し近医より紹介され た。腹部弨音波検查，CT, MRIで勝頭部に最大经 7 cmの腫痽を認め，十二指腸内視鏡検査では，乳頭部

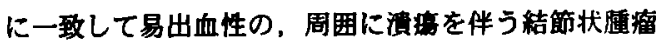
を，腹部血管造影では通㾇流染像を認めた。胸部CT で肺に異常所見を認めなかった。内視鏡下生检では， クロマチンに富んだ核を持ち，N/C比高度な腫渾紐 胞のびまん性增殖を認め，免疫組織学的にCD56陽性 で, またNSE, EMA, keratin, vimentin, LCAP易 性であった。以上から睡または十二指腸原発の小細胞 富の診断で睡頭十二指榪切除術および術中照射を施行 した。切除標本の検索では，庫癌はVater乳頭部を中 心に十二指渴壁と睡実䆩に浸泪し，睡内胆管は乳頭先 端まで開存していた。発育形㸃から十二指腸乳頭部原 発の小細胞寰之診断した。小細胞密は予後不良で放射

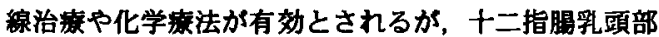
原発の小細胞癌は亟めて稀であり，その治療法に定説 はない。これらの文献的考察をふまえて報告する。

954 肝転移と肝樶倡が混在した十二指腸乳

頭部癌の1例

興生総合病院外科

○難波康男、廣瀨昌博、井上襀三、山本吉浩、

藤原佰太郎、藤原恒弘

十二指腸乳頭部瘦で肝転移と肝䐵晹が混在したが、 術前診断が困難であった症例を経験したので報告す る。

症例は66嵅、女性。平成11年1月10日右季肋部痛を 主訴に他院受診、十二指腸孚頭部癌と診断され、1月 20日当院紹介、入院となった。入院時GOT 459 IU/L、 GPT $645 \mathrm{IU} / \mathrm{L} 、 \mathrm{~T}-\mathrm{Bi}] 1.1 \mathrm{mg} / \mathrm{d} 1 、 \gamma-\mathrm{GTP} 1165 \mathrm{IU} / \mathrm{L}$ 、 ALP 3415 [U/Lであったが1月25日にはT-Bil 3.2mg/d] となったため释皮経肝胆高ドレナージを行い、2月4日 に膡頭十二指腸切除術と肝腫瘤核出術を施行した。術

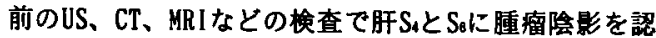
め、S、は転移、S と肝S、に佳 $20 \mathrm{~mm} 、 S_{5}$ に佳 $10 \mathrm{~mm} 、 S$ 。に怪 $30 \mathrm{~mm} 、 S_{8}$ に怪3 㿼の計4個の腫痗を認めたためそれぞれ核出街を行っ た。病理組織検查結果は術前確認できたS と $S_{8} の$ 尰瘤

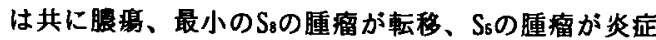
珄変化て、肝腫箅に対する術前診断の困難さを痛感さ せられた。術後経過は順調であった。 
955 日本大学第 1 外科、日本歯大学外科“

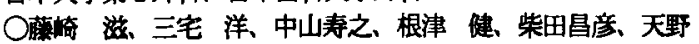
定雄、福澤正洋、富田凉一”

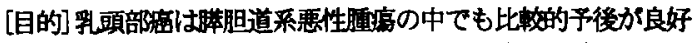
とされている。当科における乳頭部癌症例の遠隔成縜について

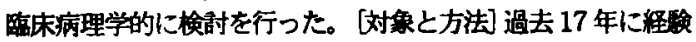
した乳頭部璐 15 例を対象とした。累稫生存率の算出は Kankan-Meier 法を、生存曲湶間の有意差倹定は Logrank 法を 用いた。[結果了男女比は $12: 3$ 、年蛉は 40-75 歲（平均 61.3 瓷)であった。H因子： $\mathrm{H}_{0} / \mathrm{H}_{1} / \mathrm{H}_{2} / \mathrm{H}_{3}$ は $12 / 0 / 1 / 2 、 P$ 因子； 全例 $\mathrm{P}_{0}, \mathrm{M}$ 因子 : 全例 $\mathrm{M}_{0}, \mathrm{du}$ 因子 : $\mathrm{du}_{0} / \mathrm{du}_{1} / \mathrm{du}_{2} / \mathrm{du}_{3} /$ 不明 は $1 / 1 / 5 / 5 / 3$, panc 因子 : Danc $/$ panc $/$ panc $2 /$ panc $/$ 不明は 6/0/5/1/3、n 因子: $n_{8} / n_{1} / n_{2} / n_{3} / n_{4} /$ 不明は 8/0/1/2/2/2。 総合的進行程度 : stage $1 / \mathbb{I} / \mathrm{III} / \mathrm{Na} / \mathrm{Mb} /$ 不明は $1 / 2 / 6 / 2 / 3 / 1$ であった。岈除術が 12 例に(荟頚十二指晹切除 10 例、乳頭部

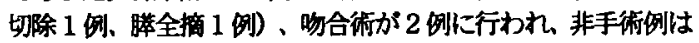
1例であった。切除例の組械型分類は pap/tub1/tub2/tub3が $1 / 4 / 4 / 3$ であった。3 年、 5 年、10 年生存率は全体で $69.3 \%$ 。 57.7\%, 38.5\%であり、切除例で 82.5\%, 72.2\%, 48.1\%、非切除例 で 50\%,0\%,0\%でった ( 0 -0.048)。 stage【以下の症例（全て 切除例) 93 年、 5 年 10 年生存率は $87.5 \%, 87.5 \%, 58.3 \%$ あったが、 stag IV 症例 $(n=5) の 1$ 年生存例はなかった $(\mathrm{p}=0.0008), \mathrm{H}, \mathrm{du}$, panc, n, 組峨型の各因子において生存率に有 意差はなかった。[結語]乳頭部癌は進展度により遗隔成績 が著しく異なった。stage III 以下の症例の予後は良好であ る一方、 stage IV 症例は予後が柾めて不良であった。

956 胆震管原発と考えられた三管合流部癌

\section{の1 切除例}

山本総合病院外科

○岡田喜克, 町支秀樹, 永井盛太、堀智英

<症例>67才，男性．右季助部痛にて入院．7年前上 り胆篦結石を指摘されていたが放置していた．入院時 現症では眼球結膜に黄染を認め，右季助部に圧痡を認 めた。検查所見で肝胆道系䣼素の上昇を認めた。腹部 CT及びUSにて肝内胆管の轻度の拡張とともに胆囊の 著明な腫大を認め.内に直径 $18 \mathrm{~mm} の$ 結石を認めた。 PTGBDを施行し造影を行ったが総胆管は造影されな かった.その後T.Bill值が $5.4 \mathrm{mg} / \mathrm{dl}$ 上昇しPTCDを施 行. 三管合流部付近での総胆管の閉塞像が認められ， 三管合流部胆管癌の術前診断にて手術を行った。術中 所見にて腫瘍は胆管にその主座があり，総胆管に浸 潤し閉塞を来したものと考えられD2リンパ節郭清を 伴う胆覆摘除及び俆外胆管切除術を施行した。切除標 本にて胆素管の腫楁は $1 \times 1 \mathrm{~cm}$, 平坦浸潤型で、総胆管へ と浸潤発育しており,組織学的に獎膜下層に達する中 分化型腺癌で $\mathrm{t} 2, \mathrm{n} 0$,stageII, 根治度はAであった。術後 経過は良好で, 7 か月目の現在再発を認めていない。 く結語〉最近経駼した胆管が原発と考えられた三管 合流部癌の一切除例を文献的考察を加え報告する.
957 故射線治䖒が著奻し7年7ヶ月生存中の

上部胆管㜔の 1 例

鳥取県立中央病院外科

○清水哲，山根成之，沢田隆，河村良宽，岸清志

胆管后に対する治㞠は外科的切除が第一選抧である が，進行瘭が多くその予後は不良である.今回，放射線治

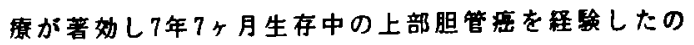
で若干の考案を加えて報告する。

症例は63留女性、主訴：黄厚、家族歴：特記すべきこ となし、既往歴：H2年1月に胆石症を指摘されていた，现 病歴: 月 3 年7月下旬より尿の黄染があり黄㾝を指摘され 当院に入完.T.Bilは9.5mg/d1と上年しており8月6日 PTCDがなされた。画像上，三管合流部を中心に胆管の閉 塞がみられ，胆计細胞診にて腺癌が証明され。上部胆管 痘と診断された。手街子定であったが减黄後もICG-R15 值が81 86\%と不良で耐術不能と判断された. 姑息的に Z-stentが留策され，H3年10月7日より11月9日まで50Gy のライナック照射がなされた，以後外来にて释過覠䋈中 であったが，H10年1月頃より黄庭が出現し再発を疑い再 入院、棈㚗の結果 Z-stent内に充满した結石による閉塞 性黄㡺と部断された.PTCSにて碎石されたが、胆道生模

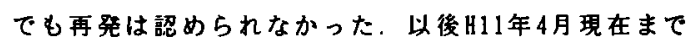
7年7ヶ月間再発兆㮢なく健在である。胆管癌に对する 治療戦略のーつとして注目すべき結果と考え報告した。

958 肝門部胆管症術後に肝照痛を綝り返し 気管支胆管撞を形成した1例 大阪更生年金病院外科、同病理科*

○清利真段、山崎元、大野喜代志、山崎芳郎、福井雄 一、㚼中信良、黄泰平、奥野慎一郎、流田弘、流鄉昌 﨏、李昌人、林明男、津田智弘、柔田圭司、小林晏”

胆管消化管吻合術後の合併症として気管支胆管庫を 形成した稀な 1 例を報告する。

症例は65歳、男性。平成7年3月、肝門部胆管照にて 旰門部胆管切除、肝門部空腸吻合術 ( t ub1 por hw 2,dw 2,ew 1)を施行した。術後より発熱を認め粗查

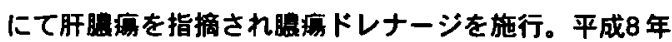

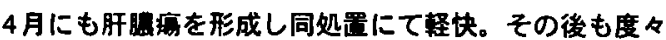
術刢よりの排㯖を認めた。同年7月より血痰、咳濑出現 乙胸部CTにて右肺 $\mathrm{S} 8,9$ 境界部に腫热性病变指摘。気管 支镜下生険を施行するも恶性所見認めず保存的治濝に より轻快。その後も咳濑の持絰とSCC(7.6ng/ ml)の上 昇を琶め大ため平成11年2月、肺癌を強く疑い入院。 喀疹は褐色胆汁様でこの時初めて気管支胆管虚を疑い PTCを施行した。肝門部空脇吻合部の狭箬は確思でき たが気管支への崖孔は確認できす、DIC-CTにて気管支

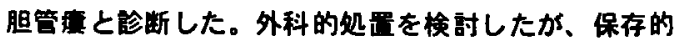
治康により整快したため外来経過観察となった。 
959 中部胆管癌根治術後 7 年後に発症し た異時性肝門部胆管癌の 1 例

防街医科大学校第 1 外科

○渡邉覚文,初瀬一夫,柿原稔、相原 司,井戸田望, 大溂康弘,川原林伸昭,乾多久夫,滝川利通,望月英隆

[症例]72 瓷、男性。[主訴]腹痛、発熱。[現病歴]中部 胆管癌の診断で 1991/6/20 膵頭十二指腸切除術を施行 (病理; moderately differentiated adenocarcinoma, INF B, ly2,vo,pn1, hinf0, ginfo,panc0, hw0, dw0, ew0,n0,stage II )。 1998/12/8 朝,主訴出現。急性化膿性胆管炎の診断で当 科菣急入院。[入院時所見]体温 39.8 度。上腹部圧痛 $(+)$ 。 眼球結膜黄染(+)。血液検查で WBC $10000 / \mathrm{mm}^{3}$, T-Bil $1.9 \mathrm{mg} / \mathrm{dl}$, ALP1569U/1, AST435, ALT 182U/l, CRP 3.9, CA19-9 $435 \mathrm{U} / 1$ 。腹部超音波検查で左右肝内胆管の 㹡張(十)。[経過]入院後直ちに経皮経肝胆道ドレナー シ術(PTBD)を施行。胆汁培養で大晹菌と肺次桿菌を 認め、細胞診は ClassIII。炎症所見の改善後、PTBD ルートから胆道鏡を施行。肝門狭窄部の生検の結果、 well to moderately differentiated adenocarcinoma であり、 初回手術㣦 7 年の経過と肝門部病変とから、異時性肝 門部胆管棠と診断。胆管造影で左右胆管への浸潤が著 明で手術不能と判断し、2/22 胆道ステントを留置し た。稀な異時性肝門部胆管窝の 1 例を報告する。

960 胆道狭窄に対する Expandable Metallic Stent(EMS) 留置の成績

山形県立河北病院外科

○大江信哉、稲葉行男、渡部修一、千葉昌和

[目的]胆道狭窄に対する Expandable Metallic Stent(EMS)の有用性と問題点を検討した。[対象] 1992 年7月から1998年 12 月までに胆道閉塞に対して EMS 留置術を施行した 21 症例を対象とした。原疾患は悪 性 19 例、良性 2 例で、平均年路は70.6 歳、男性 15 例、女性 6 例だった。使用 EMS は Wallstent が 21 個、 Strecker が 3 個、Memotherm、NT-stent が各 2 個、 Symphony、Diamond が各 1 個だった。[結果] EMS 留置成功率は $93.3 \%$ 、外掼抜去率は 90.9\%たっった。 EMS の開存率は、平均開存日数 243 日、 1 年開存率

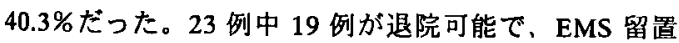
後、平均約 13 日で退院、在院死は 3 例だった。予後 は、平均生存日数 300 日、1 年生存率 $37.3 \%$ たった。 早期合併症は追加留置必要が 2 例、胆汁性腹膜炎が 2 例だった。後期合併症は、再閉塞が 8 例で、再闒塞後 の処置は、PTCD が 3 例、再ステントが 2 例、経過観 察が 2 例、手術的除去が 1 例だった。[まとめ] EMS 留㯰によって tube より解放されて自宅生活が可能に なることは、患者の QOL 向上に有用と考えられた。
961 胆管嗐切除例の治療成績

受知県がんセンター消化器外科

○清水泰博、鳥井竞人、安井健三、森本剛史、 小寺泰弘、平井 孝、山村莪孝、加藤知行

【目的】胆管癌切除例の術後成緶から、治療上の問題 点を検討した。【対象】1990年4月から1998年12月ま でに当科で切除した肝門部胆管癌を除く肝外胆管㾇20 例(男14例、女6例、平均67.1歳)を対象とした。【結果】 病変の主占拠部位はBs 3例、Bm7例、Bi10例。術式は PD11例、PpPD4 例、HPD1例、胆管切除4例で、19例 が治㾤切除 (cur A,B) であった。深達度別内訳はfm2例、 ss9例、se2例、si7例 で、n (-)/(+) 14例/6例、panc (-) $/(+)$ 9例/11例、pn $(-) /(+) 5$ 例/14例、総合的進行度は stageI 2例、stageII 7例、stageIII 2例、stageIVa 9例であ った。術後成績は、stageI、IIでは再発1例で5年生存 率89\%と良好であったが、stageIII、IVaでは11例中8例 が再発し、2年生存率 $53 \%$ で3年以上の生存は認めなか った。術後再発までの期間は118日〜765日（平均398

日）で、初再発部位は肝4例、腹膜 3 例、骨 1 例、不明 1 例。肝転移2例に肝切除を施行した。再発9例中7例が 死亡し、再発確钫後の生存日数は73日〜510日（平均 246日）であった。【結語】 stageI、II症例は治痹切除 により良好な予後が期待できる。stageIII、IV症例で は、肝および腹膜転移への対処が今後の課題である。

962

間欠的閉塞性黄疸を呈した粘液産生胆管

癌の一例

東京労災病院外科 ○石崎陽…滕代 潐、板谷光庱、

片平誠一郎、竹田 泰、宮原 透

【症例】74歳の女性。平成 3 年より肝㙨能障害を指摘さ れ軽度の黄㾝を繰り返していた。平成 6 年 6 月にPTCD を施行したところ大量の粘液を混じた胆汁の排出が認め られた。胆道造影では総胆管から左肝内胆管の著明な执 張と粘波塊による陰影欠損像が認められた。胆汁細胞 診、PTCSを行ったが確定診断がつかず、PTCDチュー フを留置したまま外来で経過観察していた。平成10年 1 月26日に胆管癌を疑って尾状葉合併拡大肝左葉切除、肝 外胆管切除、Roux-Y再建術を施行した。病理検查では well differentiated papillary adenocarcinomaで永久 摽本上胆管右枝断端が癌陽性となった。術後 1 年 3 カ月 経過したが画像診断上は再発なく外来通院中である。

考察 : 近年膵癌では粘液産生膆腫癌に関する研究がなさ れ概念が定着しつつある。一方、胆管褞にも湢床的に認 識されるほど多最の粘渡を産生するものがあり、粘液産 生胆管癌と称される。胆道造影所見は粘波塊により緿胆 管結石症に類似し、癌は表首抝大型の進展形式をとるこ とが多く診断に難沾する。本例も手術までの経過は約 7 年と長期に及んだ。今後は本疾患概念の整理とbiliary cystadenocarcinomaとの関倸の解明が望まれる。 
963

执大肝莱・肝十二指腸間膜・膵頭十二

指晹切除（H L P D） 2 例の経験

大垣市民病院外科

鈴村 絜, 山口晃弘, 磯谷正敏, 金岡祐次, 原田 徹, 高橋吉仁, 李 政秀, 菅原 元, 赤川高志, 小川敦司, 森 俊治, 北尾俊典, 笹屋高大, 新宮優二,

日比野正幸

症例 1:66才女性. 進行胆霹 (Gfb, circ, 結節浸潤 型, $7 \times 5 \mathrm{~cm}, \mathrm{~S} 3, \mathrm{Hinf} 3, \mathrm{H} 1, \mathrm{Binf} 3, \mathrm{PO}, \mathrm{N} 2(+), \mathrm{M}(-))$ に対し，訮右三区域切除、横行結腸合併切除を伴った 幽門輪温存膵頭十二指腸切除術を施行. 門脈脚部と門 脈本幹との間を $5 \mathrm{~cm}$ の右外渴骨静脈グラフトを用い て門脈血行を再建、空腸動脈第 2 枝を肝動脈外側区域 枝と吻合し血行再建を行った. 症例 $2: 70$ 才男性. 肝 門部胆管珿の著明な肝十二指腸間膜浸潤(Bl,circ,結節 浸洞型, $4 \times 4 \mathrm{~cm}$. si，Hinf3，Ginf0，Panc0 Du0，PV2， A2， n2(+)，M(-))に対し拡大肝左葉切除に上る HLPD を施行横行結腸合併切除を施行. 門脈右枝と門脈本幹 との間を $4 \mathrm{~cm}$ の右外渴骨静脈グラフトを用いて血流 再建. 中結腸動脈と右肝動脈行区域枝をマイクロ下に 再建した，症例 1 は術後安定していたが肝腆㾤で 73 病日に失い、症例 2 は術後 6 ヶ月の現在、外来通院中 である。

964 胆道系悪性腫癌におけるリンパ節微少転 移検索の試み

岡見次郎、左近買人、中森正二、塩崎 憲、大島 聡、青 木太郎、山本浩文、藤原義之、永野浩昭、堂野恵三、梅下 浩司、閏田守人 (大阪大学大学院病態制御外科)

【目的】免疫租織学的方法や分子生物学的手法を用いたリ ンパ節の微少轱移巣の検索が試みられている。今回 RTPCR 法を用いて胆道系悪性腫演における微少転移検索の 可能性について検討した。

【方法】対象症例は胆管細胞稳 6 例、胆襄癌 7 例、胆管 癌 15 例とし、まず各種癌において微少転移検索に用いら れているマーカー (CEA, CK20, Mage-1, Mage-3, PSA, AFP) について胆道系覀性腫疸組織での発現の有無を検討 した。さらにこのうち 10 例について摘出されたリンパ節 168 個より RNA を抽出し RT- PCR 法により微少転移の有 無を検索し病理学的方法と比較した。

【結果】各マーカーの腫痘組織における陽性率は CEA, CK20 で高かった。両者をマーカーとして微少転移を検索 したところ、病理学的に転移陰性リンパ節 151 個中 7 個で 転移陽性と判定されたが、病理学的に転移陽性リンパ節で PCR で転移陰性となったものも 1 個認めた。

[結語】 CEA，CK20 をマーカーとして胆道系悪性腫㻛に おける微少転移検索の可能性が示唆されたが、マーカーの 選択などさらなる検討が必要と考えられた。
965 勝サルコイドーシスの 1 例

防衛医科大学校第 1 外科

○乾 多久夫、川原林伸昭、生田真一、柿原 稳、 相原 司、大㴊康弘、初瀨一夫、望月英隆

槚めてまれな睟サルコイドーシスの 1 例を報告する。 症例は 77 紫男性。平成 10 年 1 月、背部捅が出現し近 医受診、腹部超音波検查で滕体尾部に $3.5 \times 4.5 \mathrm{~cm}$ 大 の低エコー棕城を認め、睟腫㾺の疑いで当科紹介入院 となった。血算生化学蚞查で異常值はなく、腫府マー カーは CEA が $5.6 \mathrm{ng} / \mathrm{ml}$ と轱度上昇していた。䧗部単 純 CT て睡体尾部の腫大を琶めたが、造影効果は正常 部と比較して弱かった。MRI では、T1 で low intensity、 T2 で high intensity を呈し、dynamic studyでは早期か ら造影効果がみられた。血管造影検查では、脾動脈の encasement と脾静脈の途絶を認めた。以上より侵性睛 级が最も疑われたが、有症状で䏾癌も否定できず、平 成 10 年 5 月手術となった。睟頭部は正常で、体尾部 は硬く腫大していた。術中迅速診断は僈性塐炎であっ たため、檩蔀膵体尾部切除を施行した。病理検査て、、

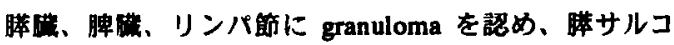
イドーシスが疑われた。術後、Ga シンチての肺門部 への集積、ツ反陰轱化、血清リソチームつ」早、红彩 炎などの所見から、睟サルコイドーシスと診断された。

966 䏽頭部に原発したと考えられた十二

指腸浸潤を伴うカルチノイド腫瘍の一例

新座志木中央総合病院 外科

○瀨尾圭亮、吉田紘一、西田二郎、高良媇、

朝野隆之、深沢雄一

症例は41歳男性。1998年3月24日腹痛にて発症し、 疼痛自制不可にて翌25日入院した。上部消化管内視鏡 検查にて、Vater乳頭部近傍肛門側に表面顆粒状白色 隆起性病変を認めた。生検組織所見では、カルチノイ ドと診断された。血管撮影およびERCP検查にて異常 所見認めず、低緊張性十二指腸造影およびMRI検查に て、十二指腸あるいは粠頭部原発の腫瘍と診断され、 4月20日勝頭十二指腸切除術を施行した。標本の病理 所見は、腫瘍細胞は類円形核を有し、リボン状に增殖 を示し、グリメウス染色陽性であった。腫瘍の大半が 脺に位置していたため、膵原発の十二指腸に浸潤した カルチノイトと診断された。1999年4月現在、再発兆 候無く外来通院中である。

若干の文献的考察を加え報告する。 
967

癌肉腫の 1 例

国立東静病院外科 ○山田卓也，尾関 豊，角 泰廣， 山内希美，坂東道哉，小田泰崇，河西克介，吉田直倩， 吉矢和久，左口武史，鈴木 実

症例は53墄，女性。1998年7月5日，吐血をきたし ため近医で精查をうけ，十二指腸乳頭部癌疑いで，当 科へ紹介された。 入院時血液検查では省血及び肝胆道 系醂素の上昇を認めた。腫瘍マーカーはCA19-9が38 $34 \mathrm{U} / \mathrm{ml}$ と著明に上昇していた．上部消化管内視鏡検 查では十二指腸乳頭部に白苔を伴う严有茎性の病変を 認め。CTでは十二指腸内に造影効果の高い病変及び 勝頭部に喜胞性の病変を認めた。またMRCPで膵管及 び総胆管、肝内胆管の抎張がみられた。 PTCD造影で は総胆管末端に高度の狭窄を認めた，以上から十二指

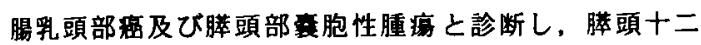
指腸切除術を施行した。病理組織学的検查では二つの 病変は連続しており，巷胞腺癌と肉腫成分が混在して いたため，癌肉腫と診断した．また，胞周囲に中分 化型管状腺癌が浸潤し，膡切離断端に癌細胞を認めた ため。放射線治療 $50.4 \mathrm{~Gy}$ 施行した。術後経過は良 好で第71病日に退院した。現在, 再発生存中である. 膵原発の癌肉腫は非常に稀な疾患で報告例も少ない．

968 聖䍮浜松病院外科

O町田浩道、小島幸次朗、島村隆浩、鈴木一史 大場宗徳、戸田央、鳥羽山滋生、中谷雄三

膵原発悪性リンパ腫の報告は極めて稀である。 我々は膵原発と考えられる瑟性リンパ腫の切除 例を経験したので報告する【症例】54歳女性 検診時の腹部超音波検查で偶然膵体部腫㨨を指 摘され来院した。血液生化学㭘査、腫瘍マ一カ 一等に異常所見はなかった。ERPでは膵管に異 常所見を認めなかった。血管造影を含めた画像 診断でも膵滰との確定診断にはいたらず、また 悪性リンパ腫の可能性も否定できず手術となっ た。平成10年11月27日脺体尾部脾合併切除術 を行った。手術時脺周囲のリンパ節腫大は認め なかった。病理組織学的検索で膵覀性リンパ腫、 follicular type. 危疫組織学的にLCA, L-

26,bcl-2が陽性であった。組䋐学的にも周辺の リンパ節に病変はなく、膵実質辺緑部から発生 した病変と考えられた。術後化学療法(CHOP) を4コース実施した。術後5力月晛在社会復帰し ている。【まとめ】自䀦例は膵以外に病変はな く、胃腸管あるいは所属りンパ節からの浸洞と は考え難かった。非常に稀な膵原発と考えられ た悪性リンパ腫の一例を報告した。
969 腆体尾部切除・門腺愣状切除を施行した 辇腺扁平上皮癌の 1 例

名古屋大学第1外科

重田英隆、神谷順一、梛野正人、上坂克彦、湯浅典 博、小田高司、佐野 力、二村雄次

症例は64歳男性。主訴は上腹部腫癣で、進行胨体部 癌の診断で入院となった。画像診断上腫瘍の最大径は $70 \mathrm{~mm}$ で、肝外側区域への浸潤像を認めた。門脈は全 周性に狭犁していた。臊体尾部切除、門脈合併切除、 肝部分切除術を施行した。上脺十二指腸静脈、下膵十 二指腸静脈、胃結腸静脈幹および左右の胃静脈のすべ てを切離した。門脈の再建は端端吻合で行い、腹腔動 脈は温存できた。腫湯最大径は $75 \mathrm{~mm} ゙$ あり、切除し た門脈の長さは $50 \mathrm{~mm}$ であった。病理組織学的には腺 扁平上皮癌、ly1, v0, ne 1, pv3, n 0 であった。胃内容の 停滞を3週間認めた。術後総胆管狭窄をきたし経皮経 肝胆道ドレナージ術を必要とした。術後血管造影では 門脈吻合部に問題を認めず、胃十二指腸および䐙頭部 へ流入した造影用は食道や空腸壁内の静脈へドレナー ジされていた。術後2月生存中である。

【まとめ】本例では門脈切除と共に、胃十二指腸お よび膡頭部の静脈はすべて切除せざるをえなかった が、臨床的に血行上の問題は認めなかった。

970 札幌厚生病院外科

○岡田邦明、近繂征文、大沢昌平、石津宽之. 西田靖仙、高橋 学、植林隆、秦席壮、 川村秀樹、紀野素久、下国達志

【症例】67鬲、男性。昭和60年に早期胃癌で幽門 侧胃切除㭪を受けた(A，Gre、I c、tub 1、sm、 1y0、v0、no)。 平成7年7月、筫血の精査で曾腸症と馀断され、結腸右

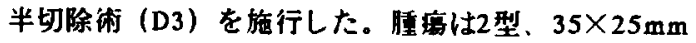
で、病理所見は高分化腺癌 se、1y3、v1、n 1(+)、stage IIIであった。平成9年1月、CEAが13.6ng/ml上昇し、

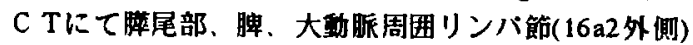
に腫富を訆めた。平成9年3月、残胃全摘、脾摘、脺尾 部切除、リンバ䬣部清を施行した。腹膜播種や肝転移 はなかった。胼尾部、脾、リンバ節の睡度は宣腸疼の 組絽像と同一で宣晹疾の転移と診断した。術後、CEA は $3.1 \mathrm{ng} / \mathrm{ml}$ と正常化した。平成10年1月より再度CEA が上昇し3月には肝伝移を契めた。平成11年1月より 被性腹膜炎となり2月に死亡した。

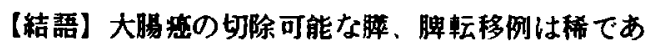
る。切除後長期生存の報告もあり皘極的に切除するこ とが㕵ましい。 
971 目摘後8年目に瞙転移を来した骨細胞痘

の1 例

大阪厚生年金外科、同病理科*

○柕田弘、山崎方郎、山崎元、福井雄一、畑中信良、

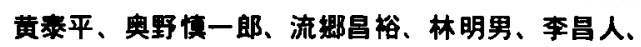
浅利自新、津田智弘、桑田圭司、山崎大”、小林 虫"

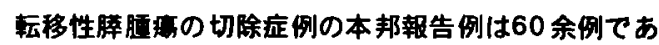
ろ.今回我々は、奋細胞症に対する左目摘後8年目に発

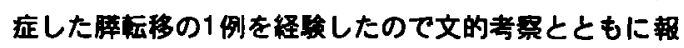
告する。症例は75宸、女性。平成2年12月、左祭細胞 癌にて左四摘と滕尾部脾合併切除を施行された。平成 10 年12月、腹部CTにて䐺頭部に $4 \times 2 \mathrm{~cm}$ の腄缯が指 摘され精查加庵目的にて入院となった。MRCPにて絰胆

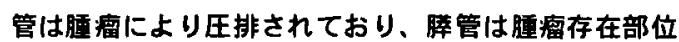
に一致して断翌像を示した。血管造影では、膘癌は浱 染像を示していた。内分泌娭查はソマトスタチンを除

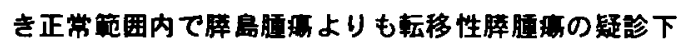
に平成11年3月、開腹術を施行した。開腹所見では、

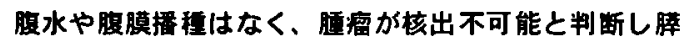
顽十二指腸切除術を施行した。睟摘出倬本の病理学梌

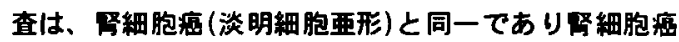
の睡枟移の確被が得られた。術後経過は概ね良好であ リ、今後インターフェロン樈法を再開する予定である。

972

1 例

腎細胞嵒の十二指腸および膵葴転移の

虎の門病院消化器外科

○橋本雅司、的場周一郎、三浦靖彦、上野正紀、 木ノ下義宏、堤 謙二、早川 健、中村豊英、 松田正道、宇田川晴司、澤田寿仁、渡䝵五朗

腎細胞癌の膵搭転移例は稀であるが十二指腸転移例 も稀である。今回、竪細胞癌の十二指腸転移巣よりの

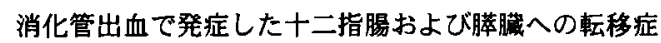
例を経験したので報告する。症例は68歳男性で1987 年左腎細胞癌に対し当院にて左腎摘出術を受けた。術 後 11 年目の 1998 年 3 月より労作時息切れを主訴に内 科入院した。 $\mathrm{Hb} 6.6 \mathrm{~g} / \mathrm{dl}$ の貣血を指摘された。上部消 化管内視鏡にて十二指腸球部から 2 部にかけて腫瘄が 認められ、そこが出血源と考えられた。腹部超音波検 查、CT検查および血管造影検查で十二指腸と膵体部 に造影勃果のある腫瘍があった。両者とも腎細胞整の 転移の診断で1998年6月幽門輪温存膡全摘術を施行し た。切除標本では十二指腸内腔に突出する $9 \times 4 \times 2 \mathrm{~cm}$ 大のI型の腫瘍と膵体部に $1.6 \times 1.3 \times 1.0 \mathrm{~cm}$ 腫演があ り両者とも明細胞型の腎細胞壆の転移であった。術後 経過は良好でインスリンを導入後退院し、術後 2 年現 在他に再発徴なく生存中である。
973

Harmonic Scalpelを用いた膵切除術

越谷市立病院外科 ${ }^{1}$ 順天堂大学第二外科 ${ }^{2}$

須鄉広之, 佐藤真輔, 瀧田尚仁, 加戸秀一 渡野邉郁雄，三上陽史，松本文夫，津村秀憲 渡部洋三”口川俊二

目的; 勝切除術に対するHarmonic Scalpelの有用性 を従来の手術手技と比較,検討した。

対象; 腈切離にHarmonic Scalpelを用いたHS群8例 とHarmonic Scalpelを用いない従来群12例を対象と した.対象術式の内訳は胃全摘膵脾合併切除14例，睟体 尾部切除6例である.

方法; 両群の比較项目として術後WBC, CRP, Amyの 推移亡術後膵液漏出の有無,Drain留置期間を比較した. 結果; 年踰, 性別, 良悪性の別,飲酒歴,術前睟管搪張の 有無、術式を比較したが両者の背景因子に差は認められ なかった.HS群と従来群の術後WBC, CRP, Amyの推 移に差は認められなかった。術後膵液漏出はHS群では 8 例中 2 例に，従来群 12 例中 5 例に認められ, Drain 留置 期間は有意差を認めないもののHS群で平均18.9日,従 来群で平均33.7日とHS群でより短かかった。

結語; Harmonic Scalpelによる膵切離は切襍中の出 血も少なく今回,有意差は認められなかったものの術後 経過は従来法に比し良好と考えられた。

974 山口大学第 2 外科

○中邑光夫, 上野富雄, 山本光太郎, 矢原 昇, 丹黒 岡 正朗

[目的］当科では膵液漏出を予防する新たな方法とし て器械(linear stapler)による睟切離の導入を行ってい る。今回その手技上の工夫および注意点を示すととも に,当科での臨床成績について紹介する。[対象と方 法]過去10年間で,当科で睟体尾部切除を施行した 89 例(器沩吻合27例, 従来法62例)を対象とし, 睟液疾の発 生頻度および睟断端のドレーン抜去までに要した日数 を従来法と比較検討した。従来法は睟断端を魚口型に

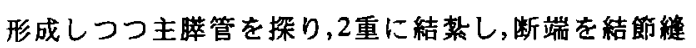
合閉鎖した。器械吻合はできる限りゆっくりと均一に 締め込んでいくことが重要で,この点から我々は睟実 質の硬さや厚みに応じて打ち込み後のサイズを調節で きるTLを使用している。[結果］従来法では62例中 23 例(37.1\%)に睟液痤を認め, 器械物合では27例中11 例 $(40.7 \%)$ に認めた。ドレーン留置期間は器械吻合 $23.6 \pm 16.5$ 日, 従来法 $19.9 \pm 11.6$ 日 $($ mean $\pm S D)$ で, 両群 間に有意な差を認めなかった。［結語］現行では睟液 瘦発生頻度を従来の手䋖いと比較して大きく低下させ てはいないが, 器械吻合器の使用は简便, 迅速で再現性 があり，臨床上有用な手術手技と思われた。 
頭十二指腸切除術(PpPD)の1例

東京女子医科大学附属第二病院外科

○猪瀬悟史, 熊沢健一, 塩澤俊一, 土屋 玲, 增田俊夫, 加藤博之, 遠藤俊吾, 吉松和彦, 木村聖美, 村山実, 辰川貫志子, 小川健治, 芳賀駿介, 暒原哲郎

エホバ証人信者の膵頭部癌に対しPpPDを無輸血にて 行い得た症例を経験したので周術期の対応と代替療 法の工夫につき報告する。症例は60歳, 男性で右季肋 部痛を主訴に平成10年5月11日, 入院となった。胆共, 総胆管結石の診断にて胆衰摘出術, T-チューブドレナー 沭を施行したが, 術後の胆道造影で下部胆管の完全 閉塞, 造影CTで膵頭部に辺緑不整な直径約 $2 \mathrm{~cm}$ の腫瘤 が描出され, 膵頭部癌と診断した。無輸血でPpPDを遂 行するために,エリスロポエチン憋郕 (epoetin $\beta$ ， $12000 \mathrm{U})$, 鉄郕60mg, $25 \%$ アルブミン $100 \mathrm{ml} 7$ 日間投与 し, Hb13.6g/dlで手術を行った。麻砕導入後に增量剤 (Hespander, $1500 \mathrm{ml}$ )の投与, 閉鎖回路による希釈式 (1000ml採血)および回収式自己血瞻血法を併用し,出血 量600ml, 最終 $\mathrm{Hb} 12.0 \mathrm{~g} / \mathrm{dl}$ で手術を終了した。無輸血手 術には失血量を最小限にする意識が必要であり,エリ スロポエチン製剤や自己血輸血の工夫により無輸血手 術の可能性と適応が拡大できるものと考えられた。

976 幽門輪温存䢁頭十二指腸切除術後の膵 液度の治療に難渋した膵獎液性震胞腺腫の一例 鹿児島大学第一外科 川井田浩一，小倉 修 曾於郡医師会立病院 肝付兼達

幽門棆温存膵頭十二指腸切除術 (PPPD) 時の膵消化管 再建方法については膵腸吻合，膵胃吻合とも一長一短か あるといわれている。今回我々は, PPPD（膵胃吻合） 術後に発生した難治性膵液瘦に対し变胃再吻合にて治 瘜せしめた症例を経験した。

症例は 55 才女性, 検診での US で睟頭部の低エコ一睡 瘤を指摘された。CT，ERCP 等にて脺頭部の萲胞性腫 㾮と診断した。ERCPにて主膵管のひきつれ像を認めた ため,悪性を否定できず平成 10 年 8 月 PPPDを行った。 腰消化管再建は脺胃吻合とし，主膵管にシリコンチュー ブ插入しロストチューブとした。術後早期より胹胃吻 合部のリークが疑われた。その後膵液瘖は正中の吻合部 付近のドレーンに一本化された。一日約 $600 \mathrm{~m}$ lの膵液 が漏出した。CT ではロストチューブが胃粘膜下に埋没 していた。術後 6 ヶ月目に再手術を行った。左上腹部の 痹着は軽度で吻合部へのアプローチは可能であった。前 回吻合部を膵，固とも揳状に切除し脺実質一胃全層を吻 合し主膵管にはチューブを留置し外瘦とした。

䐙消化管再建方法の問題点について考察し報告する。
977

術後晚期合併症における睟頭十二指腸 第 II 部切除術(PHRSD)の有用性についてPpPD各種 再建法との比較検讨

名古屋大学第二外科

○粕谷英樹、中尾昭公、金子哲也、井上総一郎、竹田 伸、野本周嗣、金住值人

【目的】当科で膵頭部良性疾患に对して施行している 膵頭十二指腸第 II 部切除政の有用性を検討する事を目 的とした。【对象】術後一年半以上を経過した症例中 PHRSD;7例, PpPD II ; 6例, PpPDII ; 10例, PpPDIV c;11例を対象とした。【万法】各吻合法に於ける術 中術後早期合併症、およひ問診による晚期合併症の調 查を行い、比梌討した。さらに健常人4例，

PHRSD;4例, PpPDIII;2例, PpPDIVc;4例に対し消化 管ホルモン分泌刺激試験を行い、術後薏隔期における gastrin, secretin, CCKの分泌状況を検討した。【結 果】早期合併症では手術時間、出血量、胃瘦tube留 置期間、術後胃液量に4群間の差を認めなかった。ま たminor leakageは4群ともに保存的に治癁した。晚 期合併症では胃もたれ感、食欲不振等の胃部不快感の 愁訴がPHRSDでは他の3群より少なかった。膵胃吻 合による胃内睟花分泌にてPpPDIVcよりPHRSDの方 がgastrin分泌反応が有意に高かった。【結語】早期 合併症では4群間に差はなく、晚期合垪症では PHRSDは有用であると考えられた。

978

境界領域膵病変に対する縮小膵切除術 の妥当性

札幌医科大学第 1 外科

○村康利、向谷充宏、中村誠志、中野昌志、

浦英榯、秦史壮、桂巻正、傳野隆一、平田公一

近年、境界領域膵病変に対して機能温存を考虑した 各種縮小手術が試みられている。1995 年からこれまで に当科で可及脺温存を目指し縮小手術を施行した 19 例につき報告する。男性 10 例、女性 9 例で、平均年 齢 58.8 藏、病理組織診断は粘液性整胞腺腫 7 例、獎液性 裹胞腺腫 4 例、震胞形成を伴う慢性膵炎 3 例、膵管内 乳頭腫場 3 例、Solid and Cystic Tumor 1 例、粘液性 賴胞腺癌(微小浸潤癌) 1 例であった。施行術式は十二 指腸温存膵頭部切除(DpPHR)8 例、膵横断切除(SR)4 例、脾温存膵体尾側切除(SrDP)6 例、その他 1 例で、 残存膵の再建を要する症例は膵空腸吻合を用いた。全 例、術後栄羡状態は良好で、退院後 3 ケ月以内に術前 体重に回復し、術前同等の社会生活を営んでいる。術 前から榶尿病を認めた 1 例を除き耐糖能低下例を認め ず、病理診断で微小浸潤癌を認めた 1 例も術後 2 年を 経過しているが無再発健存である。良悪性境界病変を 含む膆病変に対し、QOLを損なるず根治性が得られる DpPHR、SR、SrDPは妥当な術式と考えられた。 
Intestinal Stromal Tumor の一例

兵庫医科大学第一外科

○麻野泰包、豊坂昭弘、竹内雅春、関 保二、岡本英三

近年、病理学的概念として消化管における間葉系腫癌 を総括して Gastro-Intestinal Stromal Tumor (以下、 GIST)と提唱されている。今回、我々は突然の下血にて発 症した小腸腫瘍が病理組䄉学的に狭義の GIST と診断さ れた一例を経験した。【症例】 42 才男性。平成 10 年 12 月中旬突然の大量下血にて当科紹介入院。小腸造影で小 腸の圧排像、CTでは骨盤部に充実性腫演が描出された。 血管造影では上腸間膜動脈と内腸骨動脈分枝から血流を 受ける hyprevascular tumorであった。以上より小腸腫 瘍との診断で開腹。腫㾇は上部回晹の腸間膜対側より壁 外性に発育した成人手拳大の腫凛で、これとは別に膀胱 の右後面腹膜下に $\mathbf{4 c m}$ 大の腫瘤を諗めた。両腫㾇間は約 $3 \mathrm{~cm}$ で索状物で連結していた。肉眼的には悪性腫场が示 唆された。回腸部分切除と右膀胱後面の腫㿑を全摘出し た。病理所見は固有筋層より壁外に增殖する筋原性腫瘦 で、疫染色では $\alpha$-smooth muscle actin 弱陽性、CD34 強陽性、c-kit 強陽性であり low-grade malignant GIST と診断した。術後経過は良好で、現在術後 3 力月で外来に て経過観察中である。本腫瘍については従来 leiomyosarcoma と報告されてきたが、最近の免疫組織 学的研究によりその発生学的見地から GIST と論じられ ている。本例は multipleに GIST を呈した稀な症例であ るので報告する。

980

胃癌、大腸癌を同時に合併した巨大

㹕胞性平滑筋肉腫に対する1手術例

昭和大学藤が丘病院 外科

○白 英、緑川武正、伊津野久紀、前沢浩司、斉藤 充生、門倉茂樹、松本匡史、長崎秀彰、菊地浩彰、 高用茂、吉澤康男、真田 裕、熊田臨

【症例】72才男性、【主訴】腹痛,腹部澎满感【既往歴】 18年前、小腸腫瘍にて小腸部分切除術施行【経過】平 成10年4月より主訴出現し、精查、加㙩目的で入院とな る。CT、MRIにて壁の肥厚を伴う最大径 $32 \mathrm{~cm}$ の内部均 一な巨大臻胞性病変を認め、鿓胞内の出血も考えられ た。血管造影では上腸間膜動脈回腸枝からの粪胞壁の 濃染像を認め、小腸、もしくは虫垂由来の腫瘵が疑わ れた。内視鏡検查にて胃前庭部のIIC型早期癌、直腸に 0-Is型早期癌を認めた。【手術所見】腫㾇は回腸、腸

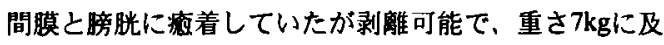
ぶ小児頭大の庭㿔と腸間膜リンパ節を摘出、同時に幽 門側胃切除、回亩部切除が行われた。【病理組織所見】 切除䅉本は免疫染色も含めて平滑筋肉腫之診断され、 同時に摘出されたリンパ節も転移と診断された。【考 察】巨大亯胞の形態を示す平滑筋肉腫の例は少なく、 更に胃、大腸重複癌を伴い、同時切除し得た1例を経験 したので、文献的考察を踏まえて報告する。
981

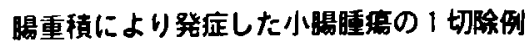
虎の門病院消化器外科

山下亮, 宇田川晴司，木下義宏，堤㴚二，上纾正紀，

中村豊英、早川健, 松田正道, 橋本雅司,

澤田寿仁，渡臬五朗

今回我々は、䀛閉塞で発症し、術前検査にて小腸腫癖 の䁑重預と訩断した症例を経験したので報告する。症例 は77筬女性、主挀は腹痛、嘔昍であった。腹部エコー にて、下腹部に径 $4.3 \mathrm{~cm}$ 大の同心円状を示す䁑管の重楮 所見を認めた。また、腹部 CTでは、重積した睗管とそ の先進部に不整な造影効果を星す睡瘦像を認めた。以上 より小腸腫癌による腸重積症と診断し、手術を族行した。

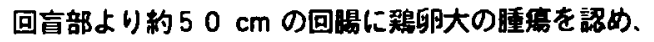
側の小腸が重積し拡張肥厚していた。病理組織訩断は。 核分裂像は目立たないか、細胞密度が非常に高く大小不 同も見られ平滑筋肉腫と訩断した。

文献的には小腸悪性腫庻のうち、平滑筋肉腫の頻度は

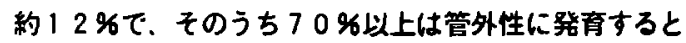
いわれている。本症例は腸重積を契機に発症した稀な管 内発育型平滑筋肉腫であった。若干の文献的考察を含め て報告する。

982

仮性覟室形成による overgrowth syndrome および二次性憩室炎を呈した空腸平滑筋肉腫の一例 岐鼻大学第 2 外科

○高木幸浩, 堅田昌弘, 森 茂, 深田代造, 佐治重量

下埱や再発性発熟発作を呈する小得平滑能肉腫の報 告例は極めて稀であるが，今回そのような空腸平滑脇肉 腫の一例を経験したので報告する。[症例] 62 歳男性, 高 度貧血の精査のため入院した。5 年前から再発する発熱 発作, 10 ヶ月前加ら繰り返す下凩・4kg の体重減少を自 觉している。左上腹部の腫鹰触知と眼瞼結膜の盆血の他， 理学的異常所見無 L。Hb. $6.2 \mathrm{~g} / \mathrm{dl}$, Fe $34 \mu 1 / \mathrm{dl}$, TIBC $252 \mu \mathrm{g} / \mathrm{dl}$, WBC $11,000 / \mathrm{mm}^{3}$, また CEA, AFP, CA19-9 は 全て正常値であった。腹部立位 X-P では左上腹部に鏡面 像を呈し, CT・MRI で腫瘦内腔, 小腸造影で内腔と空腸と の交通を確認した。開腹にて Treitz 鞋带から $25 \mathrm{~cm}$ の部

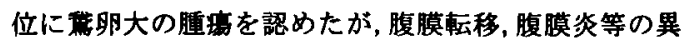
常所見は無し。腫場の一部が下行結腸に瘡着しており， 下行結渴を合併切除した。病理組織学的に小腸平滑筇肉 腫と診断された。術後,下浰・発熱発作は消失し, 1 年間 で 10kg の体重增加を認めた。[考察]腸管と交通を有す る腫鸤内空洞が巨大仮性喤室として機能し, bacterial overgromth syndrome による下利, 二次性憩室炎による発 熱発作を来し，非定型的症状を呈していたと考えられた。 